\author{
2007 개정 교육과정 초등 사회과 역사 영역 \\ 교과서 분석 \\ 김지원 · 원효헌 ${ }^{+}$ \\ (부경대학교 )
}

\title{
A Textbook Analysis on History Domain of Elementary Social Studies in the 2007 Revised Curriculum
}

\author{
Ji-Won $\mathrm{KIM} \cdot$ Hyo-Heon $\mathrm{WON}^{\dagger}$ \\ (pukyong National University)
}

\begin{abstract}
The 2007 revised social studies curriculum emphasizes history education in particular. Thus the contents of the history section previously scattered through 3rd, 4th, 5th and 6th grades are now integrated into the first and second semesters of the 5th grade in elementary social studies. Therefore, this research intend to gain insights that could be used as a reference when making next social textbooks by analyzing social textbooks of the 7 th and the 2007 revised curriculum.

The conclusions of comparative analysis on social textbooks of the 7th and the 2007 revised curriculum are as follows: The textbook units according to the 2007 revised curriculum were a reorganization of the contents from the 7th's 6th grade 1st semester contents per unit in a chronological flow. Meanwhile, the topic was introduced to supplement historic contents afresh. The 2007 revised curriculum focused on the life history, cultural history, personal history.
\end{abstract}

Key words : Textbook analysis, Elementary social studies, 2007 Revised curriculum

\section{I. 서 론}

최근 일본과 중국의 한국사 왜곡 및 일제 침략 미화, 독도 영유권 주장, 동북 공정 등으로 역사 교육을 강화할 필요성이 제기되어 2007년 개정 사회과 교육과정은 역사교육 강화를 목표로 설정 하였다. 역사영역이 특히 주목받고 있는 이유는 우리 영토를 둘러싼 주변국의 역사 왜곡과 세계 화 시대에 주체적으로 대응하기 위한 국가사회
적 요구를 반영하여 역사교육을 강화하는 방향으 로 크게 변화하였기 때문이다(교육과학기술부, 2008, p. 296).

개정된 사회과 교육과정은 초등학교급에서는 역사영역이 사회과에서 분리되지는 않았지만 중 등학교급에서의 역사 영역 독립으로 인하여 생긴 변화에 못지않은 양상을 만들어내고 있는데, 구 체적으로는 제7차 교육과정에서 4 학년, 5 학년에 서 다루고 있는 역사(인간과 시간)영역의 내용은

\footnotetext{
† Corresponding author : 051-629-5972, wonhyo@pknu.ac.kr
} 
삭제되는 동시에, 3 학년부터 6 학년까지 분산되어 있던 역사 교육 내용을 모아서 1개 학년(5학년) 에 걸쳐 한국사를 연대기 순으로 제시하는 방식 을 채택한 것으로 나타나고 있다. 이는 역사교육 을 체계화하여 내실있게 운영하고, 중복되는 내 용을 배제함으로써 학습 부담을 경감하고자 하였 는데, 사회과 교육 내용을 이루는 배경 학문 중 가장 (시간적)계열성이 존중되어야 하는 역사교 육 내용의 성격을 고려한 것이라고 볼 수 있다.

역사 영역 확대에 따른 2007년 개정 사회과 교 과서의 체제와 내용 분석은 교과서에 담긴 역사 인식을 알 수 있을 것이다. 따라서 체계적인 분 석을 통해 교과서에서 체제와 내용의 변화를 찾 는다면 이후의 교과서 편찬과 현장 교육에 시사 점을 제시할 수 있을 것이다.

본 연구의 목적은 초등학교 사회과에서의 역사 교육 강화 측면을 새롭게 개발된 교과서에서 어 떠한 형태로 반영시키고자 하였는지를 개정 전의 교과서와 비교 분석하여 체제와 내용의 변화를 살펴보는데 있고, 연구 목적을 달성하기 위한 구 체적인 연구 문제는 다음과 같다.

첫째, 제 7 차와 2007년 개정 교육과정의 초등 학교 사회과 교과서 역사 영역의 단원의 구성과 전개 체제는 어떤 차이가 있는가?

둘째, 제 7차와 2007년 개정 교육과정의 초등 학교 사회과 교과서 역사 영역의 내용 체제는 어 떤 차이가 있는가?

\section{II. 이론적 배경}

\section{1. 역사의식과 역사교육}

초등학생의 역사교육은 역사의 흐름을 통해 현 재의 우리가 어떻게 인식해야 할 것인가 하는 방 향성을 제시해 주는 것에 가장 주안점을 두고 학 습이 이루어져야 하며, 그것은 곧 '역사의식 (historical consciousness)'의 함양 과정으로 귀결 된다. 역사의식이 지향하는 역사적 능력과 태도
는 학습자의 역사의식 발달단계에 알맞은 학습지 도가 이루어질 때 더욱 발달될 수 있다.

일반적으로 정립된 학습자의 역사의식 발달단 계는 '감고의식 $\rightarrow$ 고금의식 $\rightarrow$ 변천의식 $\rightarrow$ 인과관 계의식 $\rightarrow$ 시대구조의식'이라는 종적인 발달단계 를 거쳐 형성된다(김한종, 2007, pp. 234 253). 이 는 초등학교 5학년 이르면 인물사 중심의 통사교 육과 인과관계를 파악하여 역사적 사건을 이해할 수 있다고 본 것이다. 또한 현재 역사 교육계에 는 역사적 사고력의 발달에 대하여 피아제의 인 지발달 이론을 적용하려는 주장과 이를 비판하려 는 주장이 공존한다. 전자는 피아제의 인지발달 이론에 따라 역사 학습은 형식적 조작기(11 15 세)에 가능하다는 주장을 펴고 있다. 한편, 피아 제의 인지 발달 이론이 영역 일반적 이론이라고 비판하면서 영역 특수적 인지 발달 이론을 주장 하는 입장도 있다. 일례로 이건(Eagan)은 모든 연령에서 내러티브(narrative)-즉, 담론(談論)적 방 식에 따라서 역사 학습이 가능하다는 주장을 펼 치고 있다(교육과학기술부, 2011, p. 53).

따라서 역사의식에서 역사의 시간 개념은 아동 들이 쉽게 파악하기 어려운 형태로서 점진적으로 발달해가며 초등학교 5, 6학년이 되면 인지 능력 발달 단계에 따라 역사적 사고력을 신장시킬 수 있는 시작 단계라고 볼 수 있다. 이에 따라 2007 년 개정 교육과정에서는 역사교육의 시계열성을 고려하여 5학년에 한국사를 집중적으로 배열하여 일관된 학습이 이루어지도록 구성하였다.

\section{2. 역사교육 내용의 적합성}

한국교육과정평가원에서 발행한 '초·중등학교 교과 교육 내용 적합성 분석 및 개선 방향에 관 한 워크숍'(2010)에서는 2007년 교육과정 초등 사 회과 역사 영역의 내용 적합성을 분석하였다.

분석은 '내용 선정', '내용 조직', '내용의 구현 가능성'이라는 항목에 기초하여 이루어졌다. 우선 내용 선정에서 역사 영역의 교육 목표 부합성 측 
면에서는 초·중등학교 교육과정에서 추구하는 인 간상에 부합하는 내용을 선정하는 방향으로 교과 서가 개발되었으며, 역사 영역은 연대기적, 통사 적 내용 조직의 틀에서 내용을 선정함으로써 초 등 역사 영역의 목표가 추구하는 민족사의 발전 상을 체계적으로 이해하도록 구성되었다. 또, 학 계의 연구 성과에 기초하여 인물사와 생활사를 중심으로 내용을 선정하고 구성함으로써 학습자 의 흥미, 관심을 반영한 것으로 보인다. 그러나 부분적으로 학습자의 흥미나 관심에서 먼 내용도 있다. 예를 들어, 내용적인 면에서 현대사에서는 정치사의 사건이나 사상이 중심을 이루고 있는데 이는 제 7차에 이어 2007년 교육과정에서도 나타 나고 있으며 그 내용이 많을 뿐 아니라, 내용 선 정의 일관성 부족의 문제도 있다. 내용의 조직에 서 5학년의 경우 역사 영역이 1년으로 배정되었 으나, 제7차 교육과정 6학년에 있던 내용에 더하 여 5학년에 있던 내용까지 합한 것과 여기에 비 중이 확대된 것, 새롭게 첨가된 내용도 있어 역 사 영역의 전체 분량이 대체로 과도한 편이다.

또한 단원별 성취기준의 수가 시간 배당 기준 에 비추어 볼 때 학년 내에 다 소화하기 어려운 분량으로 판단된다. 예를 들어, 대단원에서 다루 는 성취기준 수가 6 개에서 많으면 8개까지 제시 되어 편차가 크고, 대단원 내 세부 기준들에서 다루어야 할 양이나 구체성 정도도 차이가 크다. 즉 학습자의 발달 수준이 낮을 경우 학습내용이 구체적인 것이 적당하다는 주장을 적용한다면, 초등학교에서는 구체성이 높은 성취기준이 많이 포함되기는 했지만, 그럼에도 추상성이 높은 내 용도 많아 역사과 교육 내용이 학습자의 발달 수 준에 비해 어렵다고 볼 수 있다.

그리고, 학교급별 난이도의 경우에도 초등 역 사와 중학교 역사를 비교해 보면, 초등 단계의 역사가 더 어렵다는 지적이 있으며, 초등학교 경우에는 5 학년에만 역사 내용이 들어 있으므로 학교급 간 학년간 핵심적 지식·기능·가치 등의 계 속성이 유지되기 어렵다고 지적하고 있다. 여기
에 더하여 학급급 간 용어의 계속성 문제도 검토 될 필요가 있다. 마지막으로 내용의 구현에서 자 료의 한계로 교재로 구현하기 어려운 내용도 있 고, 교수학습 여건에 비추어 볼 때 학생들이 도 달하기 어려운 성취기준이나 내용 요소도 존재함 을 덧붙이고 있다.

\section{3. 역사교육과 교과서}

역사교과서의 단원 구성 및 서술은 대체로 고 대부터 현대까지 통사적으로 다루는 방식을 취하 고 있으며, 감정이나 판단의 요소가 배제된 지극 히 무미건조하고 간결한 기술을 하고 있다. 하지 만 중학교와 고등학교에 걸쳐 반복적으로 통사에 접하는 학생들은 역사에 대한 흥미를 잃기 쉽고, 그나마 시간상의 제약으로 인해 매번 피상적인 섭렵에 그칠 우려가 있다.

따라서 학년에 따라 주제별 혹은 시대별로 깊 이 있는 접근이 필요하며, 학습자 자신의 역사이 해를 확립하고 역사학습의 의미를 찾을 수 있도 록 하는 탐구 자료 및 학습 자료를 교과서에 늘 려야 한다. 또한 역사교과서는 체계적인 역사지 식의 전달 뿐만 아니라 주체적인 역사적 태도와 관점을 배양하는 데도 기여해야 한다. 이를 위해 서는 학생들이 역사 주제와 문제, 시대와 인물에 대해 스스로 해석하고 평가하는 기회를 가질 수 있는 학습활동을 포함시키는 것이 효과적이다. 역사교과서의 표현방식도 지식 제시형, 지식 나 열형에서 탈피하여 다양한 문학적 언어표현을 활 용할 필요가 있다(이정숙, 2004, pp. 29 31).

교육과정은 궁극적으로 교과서에서 다양한 역 사지식을 제시할 수 있도록 하고, 동일한 사건이 나 역사 주제에 대한 상반되는 해석을 통해 학생 들의 역사적 사고 및 역사의식을 자극하도록 구 성되어야 한다. 하지만 지나치게 상세하고 구체 적인 역사학습 목표는 오히려 창의적인 역사교과 서 제작에 걸림돌이 될 수도 있다. 


\section{3. 선행연구 고찰}

교과서를 분석한 기존의 초등학교 사회과 교과 서의 비교 분석에 관한 선행연구물들을 살펴보면 그 연구 방법을 몇 가지 갈래로 구분할 수 있다.

첫째, 교육과정 개정 전과 후의 교과서를 비교 하여 변화되고 개선된 내용을 찾는 종적인 연구 와 다른 나라 교과서와 우리나라 교과서를 비교 하는 횡적인 연구가 있다. 그리고, 종적 연구인 개정 전과 후의 교과서 비교 연구는 다시 외적 체제와 내적 체제로 구분할 수 있다. 교과서의 구성요소를 판면 구성, 활자, 편집, 판형, 지질, 여백, 제본 등 외적 체제와 단원의 체제, 내용 제 시 방식 등 내적 체제로 구분하여 분석하는 것이 다.

둘째, 분량 분석과 내용 분석의 방법으로 구분 할 수 있다. 분량 분석은 교과서의 분량을 단원 별, 시대별, 영역별로 나누어 각 부분의 분량이 교과서 전체 분량 중에서 어느 정도 차지하는가 를 조사하는 방법이다. 내용 분석은 교과서 내용 이 객관적으로 서술되었는지, 학습자의 발달단계 에 적합한지, 용어상의 어려움은 없는지 등을 심 층적으로 파악하는 방법이다.

그리고 그 외 분석의 대상을 교과서에 나오는 문자 자료로 한정하거나 비문자 자료 즉 삽화 자 료에 한정하는 연구도 있고, 문자 자료와 삽화 자료를 함께 분석하는 연구도 있다. 삽화 자료에 관한 연구의 경우, 교과서에 수록된 모든 삽화 자료를 분석하기도 하고, 특정 삽화 자료를 선택 하여 집중적으로 분석하기도 한다. 하지만 최근 에는 보다 심도 있는 교과서 비교 연구를 위해 연구방법을 복합적으로 선택하는 경향이다. 다음 에 제시된 <표 $1>$ 은 교과서 분석을 다룬 선행 연구를 요약한 것이다.

\section{III. 연구 방법}

\section{1. 분석 대상}

<표 1> 교과서 분석 선행연구

\begin{tabular}{|c|c|}
\hline 연구자 & 분석 주제 및 방법 \\
\hline $\begin{array}{l}\text { 송 춘 영 } \\
\text { (1996) }\end{array}$ & $\begin{array}{l}\text { 한.중.일 3국의 역사교과서 분석(서 } \\
\text { 술체제, 교재 단원, 교재의 분량, 서 } \\
\text { 술내용, 인물교재, 학습자료 비교 분 } \\
\text { 석) }\end{array}$ \\
\hline $\begin{array}{l}\text { 김 정 덕 } \\
\text { (2002) }\end{array}$ & $\begin{array}{l}\text { 외적·내적 체제 분석(외적 체제- 판 } \\
\text { 면 구성, 활자, 전체 쪽수, 판형, 지 } \\
\text { 질, 색도, 여백, 제본 } \\
\text { 내적 체제- 단원의 구성 체제, 단원 } \\
\text { 내용) }\end{array}$ \\
\hline $\begin{array}{l}\text { 김 진 애 } \\
\text { (2002) }\end{array}$ & $\begin{array}{l}\text { 학습자료(연대표, 역사지도, 사료, 사 } \\
\text { 진, 삽화, 도표)를 분석하여 그 구조 } \\
\text { 적 특징 및 수량에 대해 연구 }\end{array}$ \\
\hline & $\begin{array}{l}\text { 분량 분석과 질적 분석을 병행 분석 } \\
\text { (분량 분석- 단원 구성 및 단원별 내 } \\
\text { 용, 시대별.영역별 분량 } \\
\text { 질적 분석- 교과서 서술 방식, 수록 } \\
\text { 인물의 수, 삽화 자료 내용) }\end{array}$ \\
\hline $\begin{array}{l}\text { 강 경 희 } \\
(2003)\end{array}$ & $\begin{array}{l}\text { 구조와 내용의 적절성 분석(교과서 } \\
\text { 구성 체제, 단원 구성 내용, 각 단원 } \\
\text { 별 분량을 시대별·영역별로 비중도 } \\
\text { 를 분석, 등장인물의 수를 시대별·영 } \\
\text { 역별로 분석, 중국 및 일본과 관련된 } \\
\text { 서술 내용, 역사적 용어를 시대별로 } \\
\text { 분석, 삽화 및 사진 자료를 시대별· } \\
\text { 영역별 외형적, 서술적인 면에서 분 } \\
\text { 석) }\end{array}$ \\
\hline
\end{tabular}

본 연구의 분석 대상은 제7차 교육과정과 2007 개정 교육과정의 초등학교 사회 교과서 중 역사 영역으로 두 개 교육과정의 학년별 구성 내용은 다음과 같다.

\section{2. 분석 방법 및 내용}

선행 연구를 고찰해 본 결과, 개정 전 제7차와 2007 년 개정 사회과 교과서를 역사 교육 강화 측 
<표 2> 초등 사회과 교과서 역사 영역의 학년별 내용구성 비교

\begin{tabular}{|c|c|c|}
\hline $\begin{array}{l}\text { 학 } \\
\text { 년 }\end{array}$ & 제7차 교육과정 & 2007 개정 교육과정 \\
\hline $\begin{array}{l}3 \\
\text { 학 } \\
\text { 년 }\end{array}$ & $\begin{array}{l}\cdot \text { 고장 생활의 변화 } \\
\text { · 고장의 문화적 전통 }\end{array}$ & $\begin{array}{l}\cdot \text { 우리가 살아가는 곳 } \\
\cdot \text { 우리 고장의 정체성 } \\
\cdot \text { 고장의 생활 문화 } \\
\cdot \text { 사람들이 모이는 곳 } \\
\cdot \text { 이동과 의사소통 } \\
\text { 다양한 삶의 모습들 }\end{array}$ \\
\hline $\begin{array}{l}4 \\
\text { 학 } \\
\text { 년 }\end{array}$ & $\begin{array}{l}\text { · 옛 도읍지 } \\
\text { · 박물관의 기능 } \\
\text { · 문화재의 가치 }\end{array}$ & \\
\hline $\begin{array}{l}5 \\
\text { 학 } \\
\text { 년 }\end{array}$ & $\begin{array}{l}\text { - 인간 생활과 과학 기술의 관계 } \\
\text { · 조상들의 공동체 의식 }\end{array}$ & $\begin{array}{l}\text { · 하나된 겨레 } \\
\text { · 다양한 문화가 발전한 고려 } \\
\text { · 유교 전통이 자리 잡은 조선 } \\
\text { · 조선 사회의 새로운 움직임 } \\
\text { · 새로운 문물의 수용과 민족운동 } \\
\text { · 대한민국의 발전과 오늘의 우리 }\end{array}$ \\
\hline $\begin{array}{l}6 \\
\text { 학 } \\
\text { 년 }\end{array}$ & $\begin{array}{l}\text { ·국가의 성립과 발전 } \\
\text { · 근대화와 민주 국가 건설 } \\
\text { · 역사적 인물과 사건 }\end{array}$ & \\
\hline
\end{tabular}

출처 : 교육부(1999). 초등학교 교육과정 해설(III): 국어, 도덕, 사회. 대한교과서주식회사; 교육과학기술부(2008). 초등학교 교육과정 해설(III): 국어, 도덕, 사회. 한솔사. p. 315.

면에서 비교하는 분석은 지금까지 이루어지지 않 아 의미 있는 연구가 될 것이다. 교과서를 비교 하는 방법은 종적인 연구가 타당할 것이며, 교과 서의 외적 체제는 형식에 불과하여 학습에 실질 적인 영향을 미치지 않기 때문에 내적 체제를 중 심으로 분석하는 것이 가치 있을 것이다. 하지만 본 연구자의 연구 내용인 역사교육의 강화 측면 에서는 단순한 종적, 내적 체제의 연구만으로는 부족하여 연구의 방법을 복합적으로 선택하고자 하여 선행연구물(김향임, 2003)을 참고로 하여 분 량 분석과 내용 분석의 방법을 병행 채택하고자 하였다.

학습 자료의 분석은 김진애(2002)를 참고하여 그림, 사진, 역사지도, 연표, 사료 등 5 가지로 구 분하여 분석하였고, 역사적 용어, 역사인물 및 국 제 관계 분석은 강경희(2003)를 참고하여 분석하
였다. 본 연구에서 선행연구와 그 한계점들을 바 탕으로 구체적인 분석 방법과 분석의 내용은 <표 $3>$ 과 같다.

\section{<표 3> 분석방법 및 내용}

\begin{tabular}{|c|c|}
\hline 분석방법 & 내용 \\
\hline 내용분석 & $\begin{array}{l}\text { 1. 단원의 구성 및 전개 체제 } \\
\text { 가. 단원 구성 체제 } \\
\text { 나. 단원 전개 체제 }\end{array}$ \\
\hline 분량분석 & $\begin{array}{l}\text { 2. 교과서 내용 비교 } \\
\text { 가. 시대별·영역별 분량 } \\
\text { 나. 학습자료 } \\
\text { 다. 역사적 용어 } \\
\text { 라. 역사인물 } \\
\text { 마. 국제관계 }\end{array}$ \\
\hline
\end{tabular}




\section{$\mathrm{IV}$. 분석 및 논의}

\section{1. 단원 구성 및 전개 체제}

[그림 1]에서 2007년 개정 교육과정 사회과 교 과서의 단원구성체제는 다음과 같다.

가. 단원구성체제

대강화의 방침 아래 소주제명이 생략하고 '단 원 $\rightarrow$ 주제'의 흐름으로 단순화시켜, 주제 중심의 내용 구성으로 일관성을 유지하면서 하나의 주제 를 중심으로 깊이 있게 학습하도록 했다.

(1) 단원 도입

2007 년 개정의 단원 도입에는 4 쪽 분량으로 1 , 2쪽은 단원명과 주제명을 시각 자료(연표)와 함 께 제시하고, 단원 전체를 관통하는 핵심 아이디 어(이야기 자료)와 관련된 사진이나 삽화(시각자 료)를 3,4 쪽에 배치하여 학습의 내용 및 방향을 알 수 있도록 구성되었다.

도입의 첫 부분(1, 2쪽)에는 제7차에 비해 한 단원이 다루는 시간적 범위가 좁아지다 보니 연 표가 보다 더 상세해졌다.
4쪽 밑 부분에 단원 학습을 위한 질문이 제시 되어 있는데 각 단원에서 다루게 되는 시대적 상 황이나 역사적 사실 등을 전체적으로 요약하는 방식으로 서술되어 있다.

(2) 단원 정리

2007년 개정의 단원 정리는 내용을 확인하는 학습을 포함하고, 기능·능력 중심의 학습을 위한 활동으로 구성되었다. 구체적으로 ‘이야기를 시대 의 흐름에 따라 순서대로 나열하고 각 시대별 유 물이나 문화재의 붙임 딱지 붙이기, 역사 신문 만들기, 시대를 배경으로 역할극하기, 단원에서 배운 내용을 생각 그물로 정리하기, 인물과 사건 을 중심으로 역사 연표 만들기, 사진을 보고 조 건에 맞게 이야기 꾸미기로 이루어 진 활동들은 의사 결정, 탐구 중심의 문제이기 때문에 창의적. 반성적·종합적 사고를 배양하는 데 도움이 된다. 더불어 다양한 방법으로 역사에 접근 할 수 있는 학습의 또 다른 내용으로 활용될 수 있다.

\section{(3) 주제 도입}

2007년 개정의 주제학습은 주제 도입 $\rightarrow$ 주제 전 개 $\rightarrow$ 주제 정리로 구성되어 있다. 주목할 점은 주

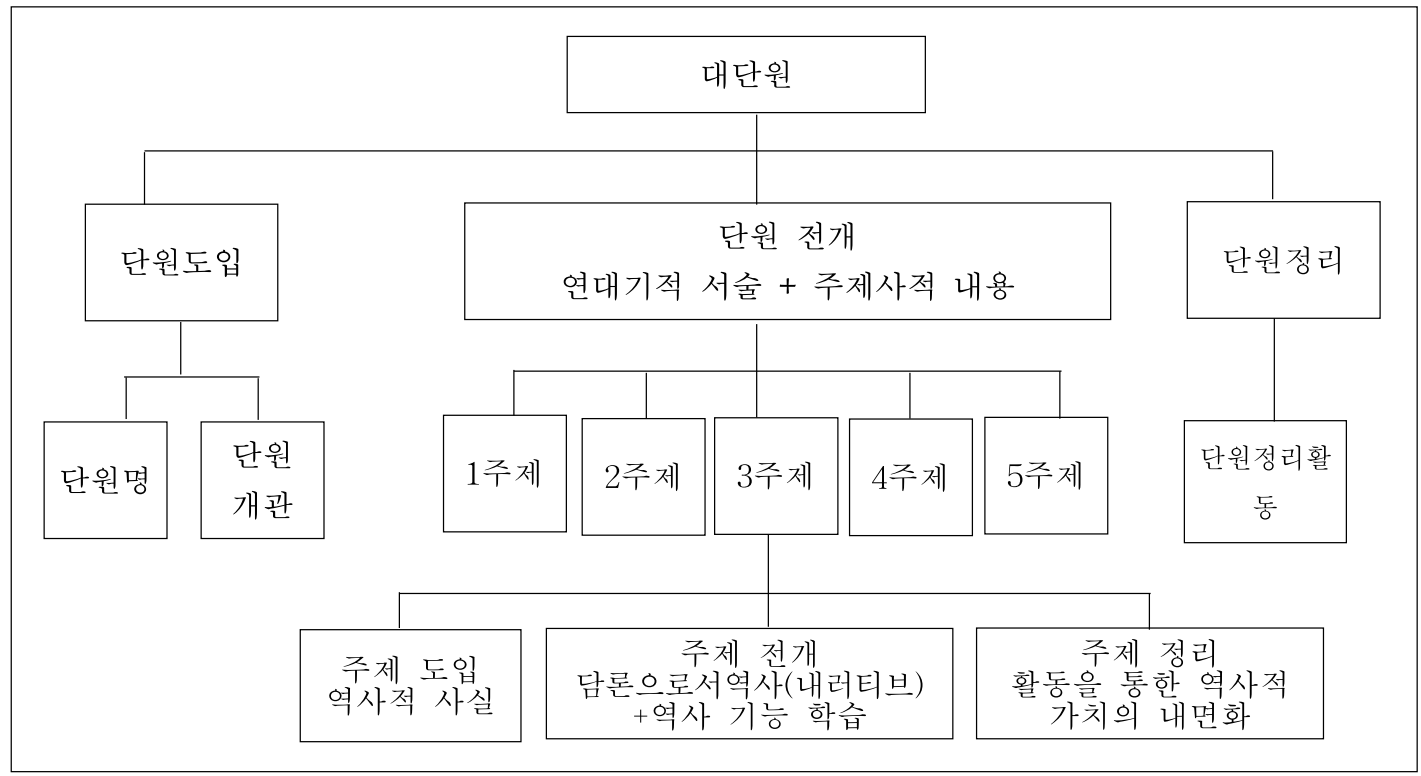

[그림 1] 단원구성체제 
요 사건을 연대기로 정리한 연표가 주제 도입에 등장한다는 점이다. 단원 도입의 연표와 달리, 주 제 도입의 연표에는 연도를 표기하지 않아서 학 습자가 사건의 발생 순서에만 집중할 수 있고, 이들 연표는 학습자의 연대기 파악력을 배양하는 데 큰 도움이 될 것으로 추정된다(배진희, 2012, pp. 21-22).

5,6 학년 교과서의 내용 구성과 전개는 3,4 학 년에 비해 상대적으로 학문적 영역이 강조되어 내용 서술 체제나 통합을 지향하는 사회과 교과 서로서 성격을 강화할 필요성이 있다. 이와 관련 하여 토픽을 구성, 제시하였다. 토픽은 주제와 관 련된 읽을거리로서, 5학년의 토픽은 초등 역사 영역의 연대기적 서술의 단조로움을 극복하고 주 제사적 내용을 보완하기 위해 도입하였다. 그러 나 토픽은 원칙적으로 본 수업의 보조적인 내용 이므로 또 다른 수업의 부담이 되지 않도록 내러 티브 서술로 구성되었다(교육과학기술부, 2011, p. 70). 역사를 배울 수 있거나 역사적으로 중요한 장소(공간)를 소개하거나 유물, 유적을 통해 알 수 있는 과거의 생활모습(시간)을 소개하고, 역사 속에서 우리나라와 주변국들과의 관계(관계), 의. 식·주, 도구들을 통해 살펴보는 과거의 생활 모습 (문화)을 소개하는 내용이 그 구성의 핵심이다.

\section{(4) 주제 정리}

주제 학습의 마지막에는 주제 정리 활동을 통 한 역사적 가치의 내면화 학습을 제시하고 있다. 그러나 일률적으로 1차시를 배정하지 않고 주제 의 내용을 확인하고 사회과 관련 기능을 익히는 활동을 구조화된 질문과 예시를 중심으로 구성되 었다. 주제 정리 학습은 워크북 구조로 된 사회 과 탐구와 짝이 되어 정리하도록 구성되어 있다.

\section{나. 단원 전개 체제}

제7차와 마찬가지로 2007년 개정도 왕조 중심 의 단원으로 구성되어 자연스럽게 시대의식을 느 낄 수 있도록 구성되었다. 그러나 제7차 교육과
정에서 왕조사, 정치사 위주의 단원으로 구성되 어 있다면 2007 개정 교육과정에서는 생활사, 문 화사, 인물사적 내용의 주제가 많아졌다.

구체적으로 2007년 개정 5학년 1학기 사회 교 과서에서는 1 단원 통일 신라와 발해 사람들, 2 단 원 불교의 영향과 고려 사람들, 고려의 과학과 기술, 3 단원 조선의 문화와 과학의 발달, 유교 전 통과 신분 질서, 조선 시대 사람들의 생활로 제 시되어 있고, 5 학년 2학기 교과서에서는 1단원 달라지는 경제생활과 신분 질서, 서민 문화의 발 달, 2 단원 근대 문물의 수용과 일상생활의 변화 처럼 생활사적인 내용들이 주제명으로 제시되었 다.

\section{2. 교과서 내용 비교}

가. 시대별·영역별 분량

제7차와 2007년 개정 사회과 교과서의 분량을 시대별·영역별로 살펴보면 <표 $4>$ 와 같다.

시대별 교재의 분량은 제7차 교육과정에서는 각 시대별로 비중의 차이가 상당히 나타났으나, 2007년 개정에서는 근세를 제외하고는 역사 내용 의 균형을 맞추려고 노력했다. 영역별 교재의 분 량을 분석해 보면 제7차에서는 정치사적 내용이 강조된 반면 2007년 개정에서는 사회·경제적 내 용이 가장 많은 비중을 차지하고 있다. 정치사 비중을 줄이는 대신 생활·문화사 내용이 더 확대 혹은 추가되었다.

\section{나. 학습자료}

제7차와 2007년 개정 사회 교과서에 제시된 학 습 자료를 분석하면 <표 $5>$ 와 같다.

<표 5>에서 분석한 학습 자료를 살펴보면 2007년 개정에서는 자료의 구분상 사료 자료가 가장 많이 늘어났고, 시기에 따른 자료의 형태를 분석하면 근대, 현대의 사료 자료의 양이 많이 늘어났다. 자료의 구분에 따른 양을 비교하면 사진 자료가 가장 많은 비중을 차지하고 있는데, 


\begin{tabular}{|c|c|c|c|c|c|}
\hline & & \multicolumn{4}{|c|}{ 영역별 } \\
\hline & & 정치 & 사회경제 & 문화 & 계 \\
\hline 제 & 고대 & 23 & 7 & 10 & $40(15.9)$ \\
\hline \multirow{3}{*}{$\begin{array}{l}7 \\
\text { 之 }\end{array}$} & 중세 & 18 & 2 & 7 & $27(10.7)$ \\
\hline & 근세 & 34 & 19 & 42 & $95(37.7)$ \\
\hline & 근대 & 51 & 7 & 4 & $62(24.6)$ \\
\hline & 현대 & 18 & 10 & - & $28(11.1)$ \\
\hline & 계 & $144(57.1)$ & $45(17.9)$ & $63(25)$ & $252(100)$ \\
\hline 2 & 고대 & 23 & 26 & 10 & $59(17.1)$ \\
\hline 0 & 중세 & 20 & 17 & 12 & $49(14.2)$ \\
\hline 0 & 근세 & 31 & 64 & 31 & $126(36.5)$ \\
\hline 7 & 근대 & 38 & 23 & - & 61(17.7) \\
\hline 녁 & 현대 & 29 & 21 & - & $50(14.5)$ \\
\hline & 계 & $141(40.8)$ & $151(43.8)$ & $53(15.4)$ & $345(100)$ \\
\hline
\end{tabular}

*고대 : 선사시대 통일신라시대 *중세 : 고려시대 *근세 : 조선 후기의 근대 문화태동기까지

*근대 : 근대 문화의 전개기 일제시대 *현대 : 광복이후

<표 $5>$ 학습자료

단위: 점(퍼센트)

\begin{tabular}{|c|c|c|c|c|c|c|c|}
\hline & & \multicolumn{6}{|c|}{ 학습자료 } \\
\hline & & 그림 & 사진 & 지도 & 연표 & 사료 & 계 \\
\hline \multirow{6}{*}{ 제7차 } & 고대 & 9 & 33 & 10 & 2 & 1 & $55(19.6)$ \\
\hline & 중세 & 9 & 16 & 2 & 1 & - & $28(10.0)$ \\
\hline & 근세 & 33 & 29 & 5 & - & 7 & $74(26.4)$ \\
\hline & 근대 & 14 & 52 & 1 & 3 & 8 & $78(27.9)$ \\
\hline & 현대 & 4 & 40 & - & 1 & - & $45(16.1)$ \\
\hline & 계 & $69(24.6)$ & $170(60.8)$ & $18(6.4)$ & $7(2.5)$ & $16(5.7)$ & $280(100)$ \\
\hline \multirow{6}{*}{$\begin{array}{l}2 \\
0 \\
0 \\
7 \\
\text { 년 }\end{array}$} & 고대 & 7 & 85 & 11 & 1 & 2 & $106(20.3)$ \\
\hline & 중세 & 12 & 20 & 6 & 1 & 2 & $41(7.8)$ \\
\hline & 근세 & 16 & 21 & 8 & 1 & 10 & $56(10.7)$ \\
\hline & 근대 & 22 & 85 & 6 & 6 & 40 & $159(30.4)$ \\
\hline & 현대 & 2 & 141 & 1 & 8 & 12 & $162(30.8)$ \\
\hline & 계 & $59(11.2)$ & $351(66.9)$ & $32(6.1)$ & $17(3.2)$ & $66(12.5)$ & $525(100)$ \\
\hline
\end{tabular}

그에 비해 교과서에 제시된 연표나 사료의 양 은 상대적으로 적다.

(1) 그림

제7차의 가장 두드러지는 특징은 만화처럼 표
현하고, 교과서에 캐릭터가 등장하기도 한다. 제7 차 교과서에는 그림 69점이 수록되어 있어 총 학 습자료의 $24.6 \%$ 를 차지한다. 그에 비해 2007년 개정 사회 교과서에 나오는 그림은 모두 59점이 며 $11.2 \%$ 를 차지하고 있다. 제7차와 달리 캐릭터 
와 같은 자료는 전혀 사용하지 않았다. 개수의 차이는 적으나 전체 학습자료가 두 배 가량 증가 했다는 점에서 그림의 비율이 상당히 줄었음을 알 수 있다.

또, 2007년 개정 교과서의 그림은 실제적으로 표현한 수채화 그림으로서 제시하고 있다. 그림 을 사실적으로 표현하면 학생들은 실감나게 과거 를 느낄 수 있으며, 학습의 효과를 증대시켜 줄 수 있다.

(2) 사진

제7차에서는 170 점의 사진자료를 실어 전체 학 습자료 중 $60.8 \%$ 를 차지하고 있으며, 2007년 개 정에서는 351점(66.9\%)으로 제7차와 2007년 개정 모두 학습자료 중에서 가장 높은 비중을 차지하 였다. 시대에 따른 사진 자료의 형태를 분석하면 고대, 근대, 현대의 사진 자료의 양이 많이 늘어 났음을 알 수 있다. 특히 고대사 부분의 양이 증가한 것은 고대사 부분의 학문적 연구 성과를 반영한 것으로 볼 수 있을 것이다. 다만 아쉬운 점이 있다면 제7차와 2007년 개정 모두, 대부분 의 사진에 제목을 붙여서 안내를 하였지만, 설명 이 없는 사진도 있었다. 그리고 설명에는 사진자 료에 대한 소재지 또는 소장하고 있는 곳 등의 자료에 대한 정보도 함께 제시하는 등 세심하게 살펴봐야 할 부분이다.

기록의 형태인 사진자료는 현대에 와서는 자료 의 수량이 풍부해졌다. 단순히 많은 자료를 확보 하여 싣는 것보다는 학습 동기 유발이나 이해력 을 고취시키는 의미에서 혹은 학생들의 발달 수 준에 맞도록 선정해야 하며 자료들의 위치 및 본 문과의 관련성을 고려해서 배치가 이루어 질 수 있도록 좀 더 세심하게 재구성할 필요가 있다. 또, 사회와 사회과 탐구에 서로 중복되지 않도록 해야 보다 폭 넓은 자료를 제시 할 수 있을 것이 다.

(3) 역사지도

제7차 사회 교과서에는 18 점(6.4\%)의 역사지도
가, 2007 년 개정 사회 교과서에는 32점 $(6.1 \%)$ 의 역사지도가 수록되어 있는데, 2007년 개정에서는 역사지도상에 옛 지명을 표기할 때 되도록 현재 지명을 함께 표기하였다. 이는 옛 지명과 현재의 지명을 관련시켜 역사적 중요한 사실이나 사상이 일어난 지역을 바르게 파악할 수 있도록 제시하 였다고 볼 수 있다.

한편, 2007년 개정에는 좀 더 의미 있는 탐구 가 가능하도록 역사지도를 가공하여 수록한 경우 가 있다. 고조선의 세력 범위를 나타낸 역사지도 의 경우, 제7차의 지도는 고조선의 세력 범위를 단순하게 색으로 표시하였다. 반면에 2007년 개 정의 역사지도는 고조선의 세력 범위를 비파형 동검 분포 지역, 탁자 모양 고인돌 분포 지역과 함께 나타냄으로써 학습자는 고조선이 청동기 문 화를 기반으로 발달한 나라임을 확인 할 수 있 다.

아쉬운 점은 역사지도에 울릉도와 독도의 지명 을 표기하도록 해야 할 것이다. 울릉도와 독도가 표기된 지도도 있지만 내용상 명칭이 생략된 지 도가 나타나기도 한다. 특히 고대, 중세, 근대사 에는 울릉도에 '우산'이라는 이름으로 표기가 되 어 있고, 독도는 위치만 표시되어 있을 뿐 이름 은 단 한 곳도 나타나지 않았다. 독도에 관한 내용은 2007년 개정에는 토픽의 한 주제로 선정 되어 있지만 자료의 정확성 측면에서도 지증왕 이후의 고대사 자료에는 반드시 명칭의 표기가 있어야 할 필요가 있을 듯하다.

(4) 연표

제7차 교과서에 수록되어 있는 연표는 7점 (2.5\%)이고, 2007년 개정에서는 17점(3.2\%)로 학 습 자료 중에서 가장 적은 자료가 제시 되어 있 다. 하지만 2007년 개정에서는 단원의 도입부와 주제 도입에 나오는 연표가 시대별·주제별로 제 시되어 실제 연표의 개수는 38 개로 늘어나게 되 었다.

(5) 사료 
제7차의 사료는 모두 16점(5.7\%)이고, 2007년 개정에서는 66점( $12.5 \%)$ 로 근세 이후의 것이 대 부분이다. 2007년 개정에서는 다양한 사료를 제 시하여 학생들의 이해를 높이고 관심을 끌려고 노력하였다.

사료는 역사 연구와 역사 교육에 있어서 중요 한 자료이지만 대부분의 사료가 한자로 쓰여 있 어 학습자가 혼자 힘으로 해독하기 힘들다는 문 제점이 있다. 그러므로 교과서에 사료를 실을 때 는, 사료를 한글로 번역하거나 초등학생의 발달 단계에 맞게 제시하여 사료학습을 통한 탐구 능 력과 역사 연구 방법을 체득할 수 있도록 해야 할 것이다(배진희, 2012, pp. 77-78). 단순히 사료 의 사진을 보여 주는 것은 의미가 없으며 5 학년 1 학기 사회교과서 119 쪽에 제시된 송순의 분재기 나 120 쪽에 제시된 노비 추쇄 문건과 같은 1 차 사료에 한자어를 해석해서 어떤 내용이 담겨 있 는지 알 수 있도록 학생들에게 제시해야 한다(최 윤정, 2012, p. 72).

또한 문화재의 위치 또는 소장하고 있는 곳에 대한 설명과 역사적 인물, 유물 및 유적, 전설 등 우리 고장에서 구할 수 있는 자료도 포함시킬 수 있을 것이다. 현대사는 다른 이전의 시대에 비하 여 풍부한 사료가 남아 있는 경우가 많다. 이는 학생들에게 직접 사료를 통해 학습할 수 있는 기 회가 많이 제공되어야 한다는 것을 말해 준다. 학생들은 사료를 직접 읽어봄으로써 역사적 사실 을 생생히 실감할 수 있다.

\section{다. 역사 용어}

2007년 개정에서는 역사적 용어가 각 시대별로 줄이려고 노력하였으나, 아직도 초등학생 단계에 서는 정확하게 알기 힘든 용어들이 많다.

역사 용어에는 명칭적 용어와 개념적 용어로 나눌 수 있는데, 역사교재에는 명칭적 용어가 많 다. 역사 용어에 담긴 의미와 성격, 개념을 바르 게 지도할 수 있도록 세심한 배려가 있어야 할 것이며, 학습자의 발달 단계에 맞도록 충분한 검
토와 연구가 있어야 할 것이다(송춘영, 2001, p. 196; 강경희, 2003, p. 66에서 재인용). 2007년 개 정에서는 역사에 대한 이해력을 높이기 위한 방 안으로서 본문 옆의 여백을 활용하여 교과서에 낱말의 뜻풀이를 제공하였다.

\section{라. 역사 인물}

제7차의 인물 수는 총 160 명이고, 2007년 개정 에서는 총 167 명으로 2007 년 개정에서 제시하는 인물이 7 명 더 많다. 시대별 등장인물의 수는 제 7차에서는 근대의 인물이 많았고, 2007년 개정에 서는 근세의 인물이 많이 등장하는데 이는 임진 왜란 서술에서 의병장 등의 인물을 많이 제시했 기 때문이다. 한국 역사교육 학계에서는 학습자 의 발달 수준의 측면에서 볼 때 초등에서 인물 사, 구체적 생활사 중심으로 내용을 선정할 것을 제안한다. 그러한 주장에 비추어 보면 2007년 개 정에서는 그러한 학계의 성과를 반영했다고 볼 수 있다.

제7차와 달리 2007년 개정에서는 고려시대, 조 선 전기와 후기의 여성의 삶이 추가되었다. 토픽 을 통해서 사회 분위기 때문에 재능을 높이 평가 받지 못한 허난설헌과 기생의 신분에서 벗어나 상인을 상대로 장사를 한 김만덕을 소개하고 있 다(배진희, 2012, pp. 38-39).

\section{마. 국제 관계}

일본의 역사 교과서 왜곡과 중국의 동북공정은 우리로 하여금 우리나라 역사 교육의 문제점을 직시하게 만들었다. 하지만 이에 대응하여 역사 교육에서 민족주의를 강화하는 방식으로는 끊임 없는 대립만을 낳을 뿐이다. 상호 이해의 관점에 서 공동의 역사 인식을 만들어야 한다는 의견의 대두는 세계사를 다루기 전인 초등학생들에게 일 본, 중국 등 우리나라와 관련된 주변국과의 관계 를 좀 더 객관적으로 바라볼 필요가 있음을 강조 하고 있다고 볼 수 있다.

(1) 중국관련 서술내용

제7차와 2007년 개정에서 제시된 중국관련 서 
술내용을 분석하면 중국 관련 서술 분량은 제7차 에서는 총 24면이고 2007년 개정에서는 총 39면 에 걸쳐 서술되어 있다.

전반적으로 2007년 개정에서도 두 나라 사이의 서술 내용에는 중국을 통해 불교가 전파되었고, 새로운 기술과 문물을 받아들여 학문, 과학, 기술 등 우리나라에 영향을 준 내용과 함께 끊임없이 이어지는 침략과 이에 대응하여 싸우는 우리 조 상들의 모습도 서술되어 있다. 하지만 2007년 개 정에서는 고조선의 세력 범위를 비파형 동검, 탁 자 모양 고인돌, 미송리식 토기 분포 지역과 함 께 제시하여 청동기 문화를 기반으로 형성된 최 초의 국가의 모습으로 서술하였다.

또한 몽고 침략에 맞선 고려의 저항으로 강화 도 천도, 삼별초의 항쟁과 함께 공민왕의 개혁 정치에 관한 내용이 추가되었다. 우리 조상들의 용기와 슬기를 배우게 하고 발전상을 체계적으로 이해시키기 위해서는 두 나라 사이의 침략과 전 쟁 관련 내용보다 문화적 교류와 역사적 유대관 계에 더 치중하여 서술해야 할 것이다.

(2) 일본관련 서술내용

제7차와 2007년 개정에서 제시된 일본관련 서 술내용을 분석하면 분량은 제 7 차에서는 총 31 면 이고, 2007년 개정에서는 총 32면으로 나타났다. 일본과 관련된 서술 내용은 삼국시대까지는 문화 를 전파해 주고 일본에서는 문화를 수용하는 입 장으로 서술되었는데, 조선시대 이후로는 일본과 관련된 내용이 임진왜란과 기술자 납치 및 문화 재의 소실 등으로 시작되어 강화도 조약 체결, 일제의 강제 지배 등 일본인의 만행이 서술되었 다.

특히 2007년 개정에서는 일제 강점기에 우리 민족이 겪은 고통을 비교적 자세하게 소개하였 다. 2007년 개정 교과서에는 일본의 침략이 시작 되었을 당시의 시대적 배경이나 조선의 정치적 상황 등을 좀 더 자세히 서술하였다. 그리고, 토 픽 '국외로 이주한 한국인'에서는 19세기 이후 많
은 한국인들이 만주와 연해주, 일본, 미국 등 국 외로 이주하였고, 나라 잃은 국민으로서 많은 고 통을 겪어야만 했던 내용을 서술하였다.

(3) 기타 관련나라 서술내용

기타 관련나라 서술내용을 분석하면 분량은 제 7차에서는 총 13면이고, 2007년 개정에서는 총 31 면으로 크게 증가한 것으로 나타났다. 이는 제 7 차 교육과정에서 부족했던 현대사 부분에서 국 제 관계의 내용이 추가되었기 때문이다. 그리고, 경제 협력 기구의 가입과 외환위기의 극복 과정, 1988년 서울 올림픽 대회와 2002년 한.일 월드컵 축구 대회의 개최 그리고 북한을 사회주의 정부 로 인정하면서 정치와 경제, 사회에 대해 언급한 점이 추가 되었다.

기타 관련 나라의 서술 내용을 분석해 보면, 중국 및 일본과 마찬가지로 국난과 이를 극복해 가는 과정을 서술한 내용이 많은데, 이는 원인과 결과 및 의의를 규명하고, 사실과 시대적 배경과 의 관계를 파악하는 능력을 갖게 하는데 적합하 다고 생각한다. 또한, 연대기적 접근 방법으로 서 술되는 교과서 서술 방식으로 나아가되 보다 넓 은 시야를 갖고 국제관계의 이해를 심화시킬 수 있도록 해야 할 것이다. 교과서의 내용은 객관적 자료에 바탕하여 사실을 왜곡해서는 안 될 것이 고, 특히 주변국과의 관계에 있어서 중국과 일본 사에 관련된 내용은 주체적 역사인식과 세계사적 시야에서 한국사의 파악을 위한 구체적 자료의 제시와 서술이 있어야 할 것이다.

\section{$\mathrm{V}$. 결론 및 제언}

\section{1. 결론}

본 연구에서 비교 분석한 결과를 기초한 결론 은 다음과 같다.

첫째, 단원 구성 체제에서 단원과 주제 도입에 서 연표를 사용하여 연대기 순으로 내용을 배열 하였다. 2007년 개정의 연표는 제7차 보다 더욱 
상세해졌고, 특히 주제 도입의 연표는 연도를 표 기하기 않아서 사건의 발생 순서에 집중할 수 있 게 하였다. 한편 토픽은 이런 연대기적 주제 설 정 방식이 줄 수 있는 단조로움을 극복하고 주제 사적 내용을 보완하기 위해 새로이 도입되었다. 주제 정리 활동에서는 역사적 가치의 내면화 학 습을 제시하고, 단원 정리는 역사에 접근할 수 있는 활동으로 창의적·반성적·종합적 사고를 배양 하는 데 도움이 되도록 구성하였다.

둘째, 단원 전개 체제에서는 생활사, 문화사, 인물사적 내용의 주제가 많아졌다.

셋째, 교과서의 내용 분석에서 초등학교 사회 과 교과서 단원의 시대별·영역별 분량은 시대별 로는 근세를 제외한 전시대 역사 내용을 골고루 안배하려고 노력했다. 또한 정치사의 비중을 줄 이고 생활문화사의 내용을 늘렸다.

넷째, 학습자료 분석에서, 자료 구분상 사료 자 료가 가장 많이 늘어났고, 근대, 현대의 사료 자 료의 양이 많이 늘어났다. 또, 사료는 2007년 개 정에 와서 한글로 번역하여 제시하려는 노력이 시도되었다. 자료의 양을 비교하면 사진 자료가 가장 많은 비중을 차지하고 있는데, 그에 비해 제시된 연표나 사료의 양은 상대적으로 적었다. 사진 자료는 교육의 효과적인 면의 강조와 더불 어 학문적 연구 성과의 결과로 고대사 부분이 증 가하고 근대와 현대로 진행되면서 자료가 풍부해 졌다. 그림은 개수의 차이는 적으나 전체 학습자 료가 두 배 가량 증가했다는 점에서 비율이 상당 히 줄었다. 2007년 개정의 그림은 실제적으로 표 현한 수채화 그림으로서 제시하고 있는데 사실감 을 살리고 세밀하게 표현되어 학습에 필요한 자 료로써의 효과를 증대시켜 줄 수 있다. 역사지도 에는 옛 지명과 함께 현재 지명을 병기하여 학습 의 이해도를 높였고, 2007 년 개정에 추가된 역사 지도는 다양한 역사적 사실을 표현할 수 있게 하 였다. 연표는 학습 자료 중에서 가장 적게 제시 되어있지만 2007년 개정에서는 단원의 도입부와 주제 도입에 나오는 연표가 제시되어 실제 연표
의 개수는 늘어나게 되었다.

다섯째, 역사적 용어의 면에서, 역사 이해력을 높이기 위한 방안으로서 2007년 개정에서는 제7 차 보다 뜻풀이된 낱말의 수가 늘었다.

여섯째, 역사 인물에서 여성 인물을 기술한 부 분이 증가했으며, 다양한 계층의 인물을 수록하 고자 하였다.

마지막으로, 국제 관계의 경우, 일본과의 대외 관계에서는 제 7 차에 비해 일제 침략의 시작부터 의 일본인의 만행위주로 서술되었는데 당시의 시 대적 배경이나 조선의 침략적 상황 등을 비교적 자세히 제시하였다. 특히 기타 관련 나라 서술 내용 부분에서는 현대사로 가면서 점차 국제화 시대에서 세계를 인식하는 교육의 일환으로 외국 과의 관계를 바라보도록 구성하려는 노력이 시도 되었다.

역사교육에 있어서 교과서는 학습자가 역사에 관해 홍미를 가지고 역사 공부에 임하며 그 과정 에서 역사의식과 역사적 사고력을 계발 할 수 있 도록 쉽고 재미있게 만들어져야 한다. 2007년 개 정 교육과정은 기존에 $3,4,5,6$ 학년에 걸쳐 배 치하였던 역사영역의 내용을 통합하여 5 학년 1 , 2학기에 걸쳐 편성하였고, 한국사의 시계열성을 살리면서 초등학생들에게 쉽게 다가 갈 수 있는 생활사, 문화사, 인물사 중심으로 내용을 구성한 것이 특징이다.

시수의 확대는 외형상 역사교육 강화라는 명분 을 충족시켜 줄 수 있는 방식으로 간주될 수 있 다. 또한, 연표와 주제사 중심의 토픽, 전시대 역 사 영역의 고른 안배, 학습자료의 양적 증가, 근. 현대사 사료의 증가, 사료의 한글 번역화 작업, 역사 용어의 뜻풀이, 여성사 비중의 증가와 인물 사, 생활사, 문화사 중심으로 내용 서술, 일제 침 략의 자세한 서술 등은 학습자의 역사의식의 함 양에 긍정적인 효과로 작용했다고 볼 수 있다. 따라서, 2007년 개정 교육과정은 외형적, 내용적 으로 볼 때 역사교육 강화의 목적을 실현했다고 판단할 수 있다. 


\section{2. 제언}

2007년 개정 사회과 교육과정에서 역사영역은 많은 변화가 있었다. 이러한 변화에 맞추어 나온 사회과 교과서는 교육과정을 반영하는 교수·학습 활동의 기본 도서이므로 학교 현장에 중요하게 취급되고 있다. 하지만 역사영역의 시간과 양의 증가로 인한 집중성이 기존의 6학년에게도 어려 운 역사를 어떻게 더 낮은 역사의식을 지닌 학생 들에게 가르칠 수 있을까 하는 문제가 존재한다.

2007년 개정 사회과 교육과정은 분명 매우 실 험적인 교육과정의 성격을 가지고 있다. 왜냐하 면 아직 시대성 의식의 완전한 정착을 가져오지 못한 5학년 단계에서 시대적 구분을 필요로 하는 역사적 내용을 학습하여야 하는 부담을 안고 있 기 때문이다. 가급적 시대 구분의 학습에 강조점 을 두지 않는다고 하더라고 이미 시대구분을 정 형화하여 접근하고 있는 교육과정을 볼 때, 그 학습효과에 대한 결과에 관심이 쏠리지 않을 수 없다(박인현, 2009).

교과서 내용 측면에서는 사실의 오류도 일부 있었고, 오류까지는 아니더라도 표현의 정확성, 일관성, 적절성의 측면에 문제가 되는 부분이 있 어 교과서 서술에 좀 더 세심한 관심이 요구되고 있다(전혁진 외, 2011, p. 52). 새로운 교과서는 일단 분량이 많이 늘어난 상태이기 때문에 그 전 교과서에 비해 더 많은 내용을 더 풍부하게 다룰 수 있게 되었다는 측면도 있기 때문에 결론에서 제시된 역사 교육적 측면뿐만 아니라 내용 구성 면이나 탐구자료, 학습자에 대한 배려 등은 크게 개선된 면이 많아 문제점 보다는 긍정적인 평가 를 내릴 만하다.

그러나 초등학교 현장에 부합하는 학습 효과를 거둘 수 있기 위해서는 역사적 내용의 부담감이 주는 문제점을 어느 정도는 해소 할 수 있는 방 향으로 접근해야 한다. 그러기 위해서는 초등학 생들에게 쉽게 다가갈 수 있는 주제로 그리고 쉬 운 내용으로 서술될 필요가 있다. 그리고 역사의
식은 학습자의 수준과 가정환경, 교육정도에 따 라 발단 단계에 약간의 차이가 있고 가변성이 있 기 때문에 아동들이 학습 주체가 되는 교과서 또 한 발달단계의 내용적 특성을 고려하여 다양한 방법으로 구성되어야 할 것이며, 영역 특수적 인 지 발달 이론 측면으로 모든 연령에서 가능한 교 과서의 서술방식이 내러티브적 방식으로 적극 반 영될 필요가 있다.

마지막으로 교과서의 내용에서 나타날 수 있는 사실의 오류와 표현의 정확성, 일관성, 적절성, 서술표현의 측면에 문제가 되는 부분을 최소화하 여 교과서 서술에 좀 더 세심한 관심이 반영된다 면 역사 교과서의 교육적 효과는 더욱 증대될 것 이다.

\section{참고 문헌}

강경희(2003). 초등학교 사회과 역사영역의 교과 서 분석, 제 7 차 교육과정 6학년 1학기 [사회] 와 [사회과 탐구]를 중심으로. 인천교육대학교 석사학위논문.

교육과학기술부(2008). 초등학교 교육과정 해설 (III): 국어, 도덕, 사회. 한솔사.

교육과학기술부(2009). 사회과 탐구 6-1. 대한교과 서주식회사.

교육과학기술부(2010). 사회 6-1. 대한교과서주식 회사.

교육과학기술부(2010). 사회과 초등학교 교사용 지도서 6-1. (주)두산.

교육과학기술부(2011). 사회 5-1. 두산동아(주). 교육과학기술부(2011). 사회 5-2. 두산동아(주).

교육과학기술부(2011). 사회과 초등학교 교사용 지도서 5-1. 두산동아(주).

교육과학기술부(2011). 사회과 초등학교 교사용 지도서 5-2. 두산동아(주).

교육과학기술부(2011). 사회과 탐구 5-1. 두산동아 (주).

교육과학기술부(2011). 사회과 탐구 5-2. 두산동아 (주).

교육부(1998). 초등학교 교육과정 해설(III): 국어, 도덕, 사회. 대한교과서주식회사.

김정덕(2002). 초등학교 사회과 6차, 7차 교육과 
정에 따른 교과서 체제 비교 분석, 초등학교 5 학년 사회과 교과서를 중심으로. 경인교육대학 교 석사학위논문.

김진숙(2011). 2007 개정 교육과정 5학년 1학기 사회과 교과서 삽화 및 보조자료 분석. 서울시 립대학교 석사학위논문.

김진애(2002). 초등학교 6학년 사회교과서 학습자 료 분석, 제7차 교육과정 6 학년 1 학기 국사영 역. 제주대학교 석사학위논문.

김한종(2007). 역사수업의 원리. 책과 함께.

김향임(2003). 제6차, 7차 교육과정의 초등 사회 과 역사내용 비교, 6 학년 1 학기 교과서를 중심 으로. 인천교육대학교 석사학위논문.

김흥기(2004). 제6차, 7차 교육과정의 사회과 교 과서 비교 연구, 초등학교 6학년 역사영역을 중심으로. 서울교육대학교 석사학위논문.

박인현(2009). 2007개정 교육과정 초등사회과교육 론. 교육과학사.

배진희(2012). 제7차 및 2007 개정 사회과 교육과 정의 교과서 비교 분석, 역사영역을 중심으로. 부산교육대학교 석사학위논문.
송춘영(1996). 한.중.일 3국의 초등사회과 역사교 과서의 분석, 6 학년 국사교과서를 중심으로. 대 구교육대학교 초등교육논총 제 9집, 57-94.

송춘영(2001). 역사교육의 이론과 실제. 형설출판 사.

이정숙(2004). 제7차 초·중등 국사 교육과정의 내 용 구성 비교. 경인교육대학교 석사학위논문.

전혁진 외(2011). 새 역사 교과서의 분석과 활용 방안 모색, 초등학교 5학년 사회교과서의 한국 사 내용 검토와 활용방안. 역사교육논집, 47장, 23-56.

최윤정(2012). 2007년 개정 교육과정 초등 사회과 역사 영역 분석. 경인교육대학교 석사학위논문. 한귝교육과정평가원(2010). 초·중등학교 교과 교 육 내용 적합성 분석 및 개선 방향에 관한 워 크숍. 국어과 및 사회과를 중심으로.

- 논문접수일 : 2012년 11월 01일

- 심사완료일 : 1차 - 2012년 11월 16일

- 게재확정일 : 2012년 11월 19일 